\title{
MEHU: HIS IDENTITY AND THE ARCHITECTURAL AND ARTISTIC FEATURES OF HIS TOMB
}

\author{
Shafik, S. \\ Higher Institute for Tourism \& Hotels, Luxor (EGOTH), Egypt \\ E-mail: samehshafik20@yahoo.com
}

\begin{abstract}
Located in the Wenis cemetery, Mehu's mastaba was used by three individuals of the same family, Mehu, Meryreankh and Hotepka. With its well preserved decoration and with the variety and frequently original themes depicted on its walls, the mastaba may be considered as one of the most important tombs of the Old Kingdom. The owner probably had royal blood and was also married to a daughter of a king, possibly Wenis. He held the vizierate under Wenis, Teti and early under Pepy I, and accordingly during Weserkare's reign. The architecture of Mehu's mastaba seems to have been inspired by those of Ti and Ptahhotep I, and all three influenced other mastabas, such as that of Mereruka. The artists of Mehu's chapel were very competent and paid special attention to details, but those of Meryreankh and Hotepka, were generally less capable. Similarities between Mehu's scenes and those of Mereruka are evident in the flute players amongst the harvesters, the attendants catching Egyptian mongooses by the tail in the fowling scenes, and the sleeping/preparation to sleep during the pilgrimage trips. Comparison with other tombs shows similarities, for example in the mating crocodiles (Mehu, Kagemni and Hesi), the crocodiles swallowing fish headfirst (Khnumenti at Giza and Mehu, Kagemni and Mereri at Saqqara) and the high-kicking dance (Mehu, Kagemni, Ankhmahor, and Merefnebef). However, the aggressive scenes found for instance in Mereruka's chapel are missing in that of Mehu, which may reflect his personality.
\end{abstract}

Keywords: Chapel, Cemetery, Old Kingdom, Sarcophagus, Abydos.

\section{Introduction}

The mastaba of Mehu is located in the Wenis cemetery at Saqqara, and although it is usually attributed to Mehu, the mastaba was used by three successive owners belonging to the same family. With its extremely and completely well preserved scenes and inscriptions and with the variety and frequently original themes depicted on its walls, the mastaba may be considered as one of the most important tombs of the Old Kingdom. Although known and referred to in Egyptological literature since the 1940's, the reliefs and inscriptions of the tomb remained largely inaccessible to scholars until 1998 when it was published by Hartwig Altenmüller, [1]. This publication has greatly enriched the Old Kingdom library and certainly opened many doors for research into this period. In addition to the translation of the inscriptions and an excellent description of the scenes, with reference to comparative materials, Altenmüller's work contains a superb set of black and white, and also a few colour photographs, but does not include line drawings. While this method of publication may be 
considered adequate for small objects, like false doors and stelae, and perhaps even for short tomb walls with clear decoration, it is not suitable for a tomb like that of Mehu. Because of the unusually narrow rooms of Mehu's chapel the scenes are difficult to photograph without limiting the record to close-ups of small wall spaces, which the experienced photographer Mr. Dieter Johannes of the German Institute has brilliantly produced. But it was practically impossible to obtain context photographs in order to link the many themes represented and to allow the study of the general composition of the wall decoration. The abovementioned common difficulty of photography and the need to record the minor details of each object in the scenes and of the hieroglyphic signs are the main reasons for Egyptologists continuing to produce the very demanding and time consuming detailed line drawings using appropriate light conditions for each small section of the wall. Even in the valuable new series "Egypt in Miniature", in which Harpur and Scremin relied on close-ups of the different elements in the scenes, they included complete context drawings of all the tomb walls they recorded [2]. In

\section{The Identity of Mehu}

Mehu certainly lived at one of the most interesting, but probably turbulent periods of the Old Kingdom. In addition to forty-eight titles and many epithets, he held the highest administrative office in the country, that of "Supreme judge and vizier" [1] , but when exactly he occupied the position is debatable. The location of his mastaba in the Wenis cemetery, in a street of tombs immediately opposite the mastabas of Wenis's queens, Nebet and Khenut, may well suggest that he started the building of his tomb under this king. Although due to the topography of the area Mehu's mastaba is situated at a lower level than the other adjacent mastabas, it is in one line with those of Iynefert, Wenisankh and Ihy (reused by Idut) [4]. The first and the third were viziers of addition to the high standard of art in Mehu's tomb, its scenes have retained most of their colours, making it one of the best available examples for the study of wall paintings in the Old Kingdom as well as the interaction/cooperation between the sculptor and the painter. In these respects the tomb may be compared to that of Nefer and Kahay, also at Saqqara, which is equally published in black and white photographs and with no context drawings [3]. In 2007 I obtained permission from the Supreme council of antiquities to rerecord the mastaba of Mehu, and I would like thank the SCA and particularly its Secretary General, Professor Dr. Zahi Hawass, as well as the successive Directors and staff of the Inspectorate of Saqqara for their support and help. For the last four years I was able to spend a season at Saqqara of between four and six weeks each year, and am pleased to report that the recording has now been completed, both in colour photographs and in line drawings. I would also like to thank the professional photographer Mrs. Effy Alexakis of the Australian expedition to Saqqara for photographing the entire wall scenes.

Wenis and the second held the title of "King's son of his body", probably refering to Wenis himself. A date for the start of the construction of Mehu's tomb under Wenis may also be supported by his marriage to two women, Neferkaues/Khentkaues and Nebet, who appear with him in the fishing and fowling trips [1]. The first wife is represented again in the middle room where she is designated as "King's daughter of his body", fig. (1) [1]. Nebet is not so described, but she may have enjoyed the same status, since in the fishing and fowling scenes neither of the women is so designated. But who was their father? Teti must be excluded as all his known daughters were named after his mother Zeshzeshet. The most likely 
father is Wenis and the name of Nebet coincides with that of Wenis' Queen. Daughters were frequently named after their mothers. An inscription on the façade of Mehu's mastaba states that the tomb was built for him by a "Hereditary prince" called Shepsipuptah, fig. (2) [1]. whose name appears in those of two funerary estates inscribed on the south wall of Mehu's corridor, next to two other estates named after "the king's mother Zeshzeshet", mother of King Teti, fig. (3) [1]. Kanawati has suggested that Shepsipuptah was perhaps Zeshzeshet's husband and accordingly the father of King Teti [5]. As Shepsipuptah built the tomb for Mehu he may have been either his father or his son. Baud identifies this Shepsipuptah with the similarly named prince, whose sarcophagus was discovered in Wenis' temple [6]. Although such evidence still needs further analysis, it suggests that Mehu was directly related to the monarchy, perhaps by both blood and marriage, and that may explain the richness of his tomb. Mehu's closeness to the king may also be seen in his epithet nj mrwt "possessor of love" [1], which Baud has suggested that its appearance in the Fifth Dynasty coincides with the end of the strong presence of the royal sons in certain positions. He even wonders if the epithet "possessor of love" does not express the proximity to the king and the attachment to the sovereign, in the same way as the title z3 nswt mrjj.f "king's son, his beloved" does [6]. This infrequent epithet is held for instance by the vizier Djau of Abydos [7], and by Ibi, the governor of both Deir el-Gebrawi and Abydos [8]. The first man was certainly the brotherin-law of Pepy I and the second probably belonged to the same family of Abydos [9]. If Mehu started the construction of his mastaba under Wenis, it appears to have been completed and mostly decorated under Teti. The names of his funerary estates are formed with the names of Wenis and Teti as well as the latter's mother Zeshzeshet, and these appear in the original decoration of his corridor. He certainly held the vizierate under Teti as is evident in his offering room, where he is described as "Inspector of priests of the pyramid of Teti" and "Supreme judge and vizier" [1]. But Mehu's career did not come to an end with the reign of Teti, for he continued to serve under Pepy I in whose pyramid he was also an inspector of priests. [1]. References to Pepy I however appear only on the pillars of his portico which may have been the last to be decorated. Having served under Teti and Pepi I, Mehu must have lived under the ephemeral king Weserkare, although, as is the case in all contemporary tombs, the name of this king is not mentioned in the inscriptions of the tomb. Yet, it may have been during Weserkare's reign that the external good stone walls of Mehu's mastaba were curiously cased with thick mud brick walls [1], perhaps to hide the façade inscriptions stating that the tomb was built for him by Shepsipuptah. This rather unsettled period needs further examination in which information from the tomb of Mehu must be carefully taken into consideration. The second offering room in this mastaba belongs to a man named Meryreankh who, like Mehu, held the office of vizier, almost certainly under Pepy I, in whose pyramid he was inspector of priests. The relationship of Meryreankh to Mehu is uncertain, but he may have been his son, even if his name is not mentioned among Mehu's sons in the latter's chapel. We know that officials acquired new names as new kings came to power, and it is likely that forming a name with the cartouche of a reigning king represented an honour granted by this king [10]. Many sons of the top officials of Teti added rooms in their fathers' mastabas and used them as their resting places. This feature seems to have been particularly common during the reign of Pepy I, which perhaps reflects the limited economic means of officials in this period. Examples are found in the mastabas of Ankhmahor [11], Neferseshemptah [12], Mereruka [13], and Khentika [14]. Those who built 
independent tombs usually constructed relatively small ones. That Meryreankh was directly related to Mehu, possibly as a son, may be deduced from the fact that he designed the entrance to his offering room unusually low, most probably to avoid causing any damage to the figures of Mehu and his wife already depicted immediately above the doorway. Another son of Mehu, named Hotepka, used the portico of the open court as his chapel, where he added his false door and decorated the three walls of the portico.

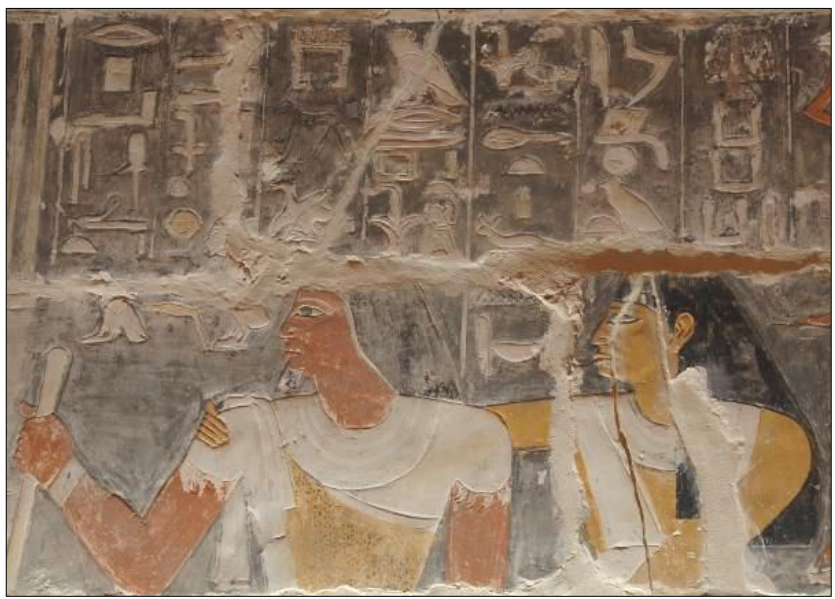

Figure (1) Mehu's wife Neferkaues / Khentkaues designated as "King's daughter of his body"

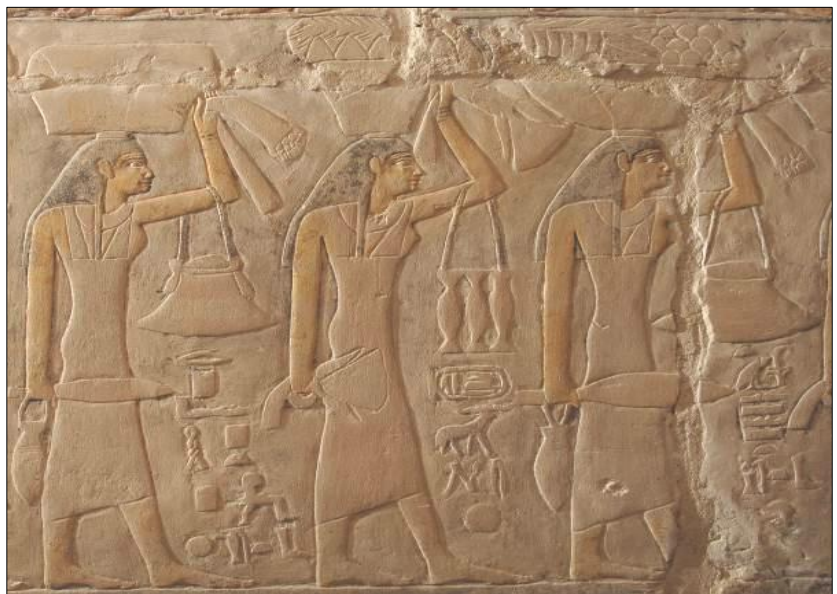

Figure (2) Façade inscription stating that Mehu's mastaba was built by Shepsipuptah

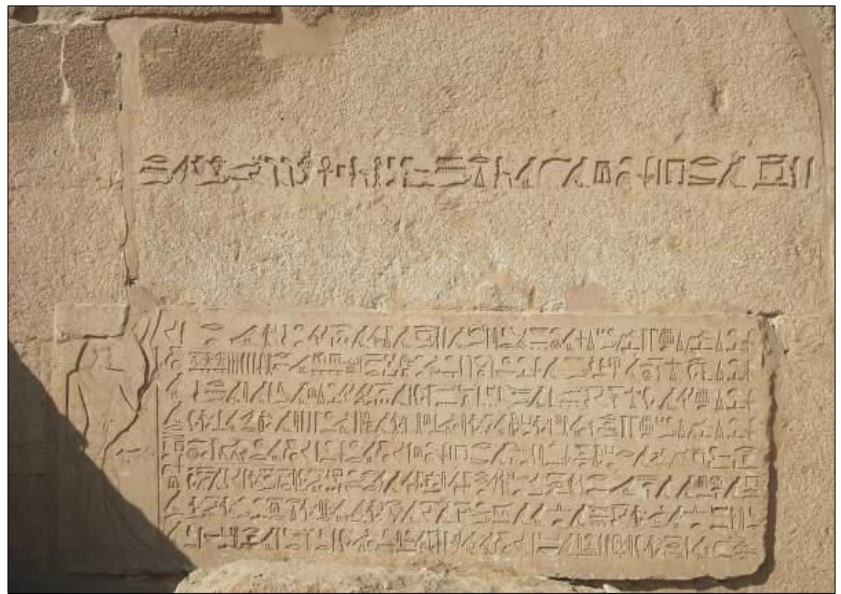

Figure (3) Names of Shepsipuptah and Zeshzeshet used in those of two funerary estates 


\section{The Architectural Features of the Mastaba}

Architecturally Mehu's chapel is formed of a small antechamber, a long narrow corridor, a small middle room, two offering rooms, a serdab and an internal open court with a portico. The main burial chamber is reached through a sloping passage, the mouth of which opens into the floor of the open court. Despite the large area allocated for the building of this mastaba, the architect clearly allocated most of it for the open court and opted to design the rest of the chapel as a set of narrow rooms. This is particularly clear in the antechamber, the middle room and certainly in the long corridor, where the walls contain the most important and informative themes of daily life. If such narrowness aimed at shortening the roofing slabs in order to avoid them cracking, it certainly achieved the desirable results. Most of the roofing slabs have actually survived in situ, and as a result the decoration remained largely protected and well preserved. If Mehu's architect had been inspired by previous buildings, the most likely ones would be the remarkable and not far distant mastabas of $\mathrm{Ti}$ [15], which has a range of dates from Niweserre to Wenis, [16] and Ptahhotep I, [17] which is dated to late Djedkare [16]. Similarities may particularly be seen in the use of a very large internal open court with a portico, a narrow decorated corridor (only in $\mathrm{Ti}$ ) and a sloping passage leading to the main burial chamber. However, Mehu's architect was less ambitious in his use of pillars, for while he used only two pillars to support the internal portico, Ti's architect used two pillars for an external portico, twelve pillars to support a portico surrounding the four walls of the internal open court and two pillars for the roof of the offering room. Ptahhotep's architect also used two pillars for the external portico, ten pillars for the portico around the walls of the internal court and probably five pillars in other rooms. The architecture of the mastabas of Mehu, Ti and Ptahhotep seem in turn to have influenced contemporary, or slightly later ones, as may be seen for example in the architectural features of the mastaba of Mereruka in the Teti cemetery [13]. Room A10 in the latter mastaba is a pillared hall with four free-standing pillars aligned north-south. Four other pillars forming a second parallel row have been incorporated into the east wall, suggesting that the design of the room was altered prior to decoration. Duell suggested that the last pillars were also free-standing, forming a portico, and that the original entrance to the mastaba was from the east, but was changed in favour of the present southern entrance [13]. That the design and purpose of room A10 has changed is almost certain, and equally likely is the fact that this space was originally intended for a portico or an open court. The four pillars presently in the middle of the room are decorated in incised relief, typical of external decoration and different even from those in Mereruka's own pillared hall A13, which are decorated in raised relief [13]. However, the suggestion that A10 was an entrance portico and that the doorway to the chapel was from the east seems unlikely. No entrance portico has two rows of pillars and the doorway connecting A10 with the rest of the chapel is at the extreme end of the west wall rather than in its centre as would be expected if it was the main entrance. The door is also too narrow, $60 \mathrm{~cm}$, to be the main entrance of the chapel. In fact the southern main entrance is $80 \mathrm{~cm}$ wide and the other doors between the different rooms are all wider than that of A10, averaging between 70 and $85 \mathrm{~cm}$. It appears that room A10 was originally designed as an internal open court, to the east of the chapel and with a particularly narrow doorway like that of Mehu, but with a portico around its four walls, like those of $\mathrm{Ti}$ and Ptahhotep. The original east wall of this open court A10 was probably further to the east, but this section of the structure seems to have been reduced to allow for the construction of Kagemni's magazines. 
The eastern wall was moved further to the west and the already existing second row of pillars was then incorporated into the now east wall [16]. The purpose of the room has changed, and as a result it

\section{The Art in Mehu's Chapel}

All the decoration in Mehu's chapel was executed in painted relief, and because of its excellent preservation we are able to study the separate roles of the sculptors and the painters in its decoration. The evidence suggests that the sculptors and painters of Mehu's own chapel; i.e., the antechamber, the corridor, the middle room and the main offering room were all competent. The sculptor who decorated the corridor in particular paid special attention to the individual features of the workmen, so much so that one can recognise possibly the same person depicted more than once on the walls of this corridor, fig. (4). On the other hand, the sculptor of the second offering room of Meryreankh was less able and his work had to be corrected and modified by the painter. The final outcome however is extremely pleasing as the painter of this room was certainly a master artist and he applied a heavy coat of paint to cover the shortcomings of the sculptor, which resulted in this room retaining a great deal of its colours. The excellent preservation of colours in Meryreankh's offering room will prove valuable in our study of the colour conventions in the Old Kingdom. But more importantly it will allow us to recognise the different types of offerings represented, including for example the different species of geese carried by the offering bearers. The Egyptian kept a number of species of birds, many of which could only be identified by the colours of their feathers. The Egyptian painter was well familiar with these species and rendered them accurately. Here we have a rare and valuable record of these species of birds and of the nature of the other offerings brought to Meryreankh. The decoration of the portico walls, belonging to Hotepka, has a unique combination of intimate themes executed in raised relief typical of internal decoration, and pillars inscribed in incised relief typical of external decoration.

shows much less merits. Having probably been decorated mostly under Teti, the artists of Mehu's mastaba were certainly working on it while the decoration of some other magnificent tombs in this king's cemetery was in progress. Perhaps all the artists of these tombs belonged to, or were trained at the royal workshop. In such a case similarities of themes and details were inevitable and the influence of the art in one tomb on that in the other, or of one master artist on his colleagues was very likely. These issues need careful consideration and I hope that the new documentation of the mastaba of Mehu will open the way for the much needed research in this area. A detailed comparison with all the tombs in the Teti cemetery is intended, but just by way of example, a quick comparison between the scenes in the mastaba of Mehu and in that of Mereruka, where I also had the opportunity to participate in its recording, shows striking similarities in subject matters and details. While some similarities may be seen in themes such as the agricultural activities, fishing and fowling, travelling by boats, etc., some common decorative features in the two chapels need to be highlighted. In general, one notices that both tomb owners prominently depicted the activities that take place on the river [1], as well as those of the agricultural pursuit[1]. It may be argued that the supervision of such activities represented an integral part of the responsibilities of the office of vizier which the two men occupied. However, while river activities are rather common and occasional agricultural activities were also depicted in the tombs of near contemporary viziers, such emphasis on agricultural pursuit is not attested in other near contemporary tombs of viziers, as for 
instance those of Ptahhotep and Akhethotep [18], Akhethotep/Hemi[19], Iynefert and Ihy [11]. It is also true that while agricultural activities appear in the tomb of the vizier Ankhmahor of Teti [20], other viziers of the same king did not give the same attention to such pursuit. Thus the theme is lacking in the tombs of Khentika [21], and Inumin dated to the end of Teti's reign and to the beginning of that of Pepy I [22]. Even Mereruka's immediate neighbour and contemporary, Kagemni, who owned a well decorated chapel, with a variety of themes depicted and a large wall space available, did not illustrate the agricultural work. [2]. An interesting detail found in both tombs of Mehu and Mereruka is the flute player entertaining the men harvesting the grain, fig s. $(5 \& 6)$ [1]. Some of the other details are worth noting as they appear only in these two contemporary tombs. Mehu represented himself seated in a papyrus boat and being presented with a goose by an attendant while watching the work of fishermen [1]. Mereruka does not appear in this position, but in a similar scene his brother, Ihy, sits in a boat holding a presumably roasted bird in his hand while being presented with a drink by an attendant [13]. In the scene of the tomb owner catching birds in the marshlands of the Delta, one of the attendants of each of these viziers is shown catching an Egyptian mongoose by the tail [1], certainly a very unusual and rare event not seen again in tomb decoration figs. (7 \& 8). In the representation of the pilgrimage trip Mehu is depicted twice in the same boat, once standing and leaning on his staff amidships and the other actually asleep on a bed at the stern of the boat, fig. (9) [1]. The closest to this representation is found in the tomb of Mereruka where the vizier is equally standing and leaning on his staff amidships while a servant is preparing the bed, fig. (10) [13]. It is implicit that Mereruka will sleep, but this is not shown. Perhaps Egyptian higher officials preferred not to show themselves in the sleeping position. The comparison of the themes and details in Mehu's chapel should not be restricted to those in the tomb of Mereruka; other near contemporary tombs may have been influenced by that of Mehu, or indeed may have influenced it, depending on the precise dating of each of these. For example under the boat where Mehu is sitting watching the fishermen are depicted two crocodiles embracing each other, in a posture which may indicate that they were mating or fighting [1] [23]. The only identical scenes are found in the tombs of Kagemni [2], and Hesi [24], both in the Teti cemetery. On the east wall of the antechamber under the papyrus boat carrying Mehu in his fowling trip a crocodile is depicted swallowing a fish headfirst. This is a rare motif which, in addition to its representation in Mehu's tomb, appeared once at Giza in the tomb of Khnumenti [25], and three times at Saqqara, twice in the tomb of Kagemni and the third in the tomb of Mereri [2], both in the Teti cemetery. It should be noticed that the second case in Kagemni's tomb shows the crocodile swallowing the fish tail first, which is contrary to the usual. In order to avoid the sharp spines of the fish from injuring the crocodile's throat and gullet, the animal manipulates the fish, tossing it in its mouth until it can be swallowed headfirst [23]. The closest parallels to Mehu's representation are therefore found in room 1 of Kagemni and in Mereri's chapel. The similarity with Kagemni may also be seen in that Mehu also depicts the so-called highkicking dance [1], where the female dancers stand on one leg with the torso thrown backwards while the other leg and the two arms are stretched forward to balance the torso's weight. This dance appears again at Saqqara only in the tombs of the viziers Kagemni [2], Ankhmahor [11], and Merefnebef [26], before it was emulated by some provincial administrators [27]. The analysis of all the scenes depicted in Mehu's tomb will no doubt add to our 
understanding of the work of the artists in the Sixth Dynasty. But if the selection of the themes in a tomb reflects the experience and character of its owner, as Kanawati has argued with regard to Mereruka [28], a study of the very richly decorated tomb of Mehu may also throw some light on his character. For instance, while Mehu depicted himself in a boat enjoying the work of fishermen, Mereruka showed his brother, not himself, in this rather casual and informal position. Also while Mehu represented himself actually asleep, Mereruka was

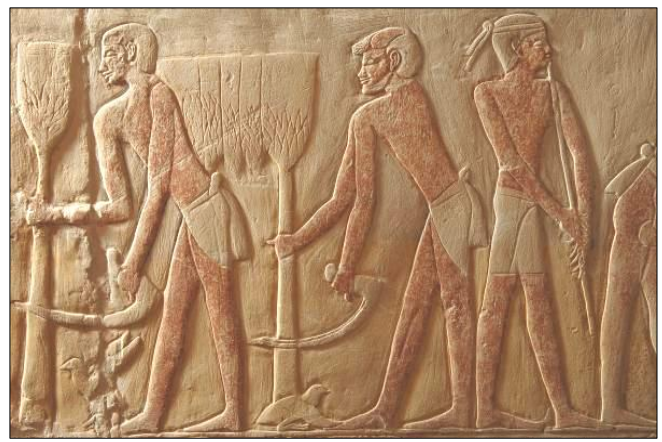

Figure (5) Flute player in the tomb of Mehu

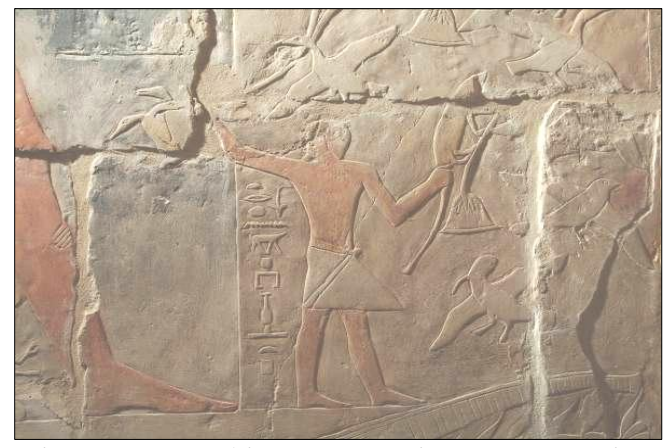

Figure (7) Catching an Egyptian mongoose in the tomb of Mehu

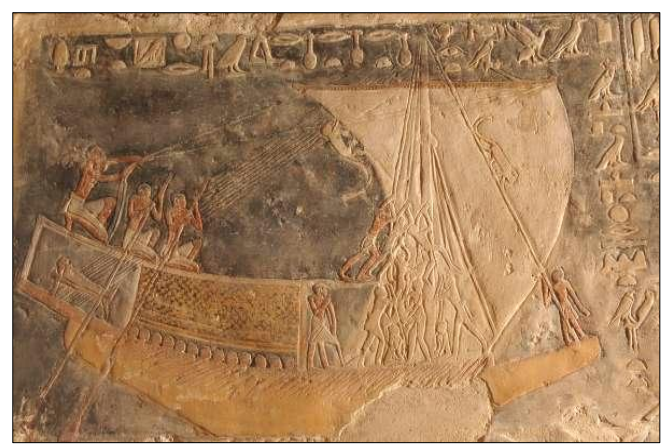

Figure (9) Mehu depicted once standing and another asleep on the same ship shown standing and waiting for the bed to be made. The significance of these scenes with regard to the personality and/or the status of their respective owners need further analysis. However, the very aggressive scenes of the harpooning of the hippopotami in the marshlands [13], the tearing apart of a Nubian ibex by a pack of nine dogs in a desert hunt [13], and the whipping of an "estate manager" at a whipping post [29], are completely missing from the repertoire of events commemorated by Mehu.

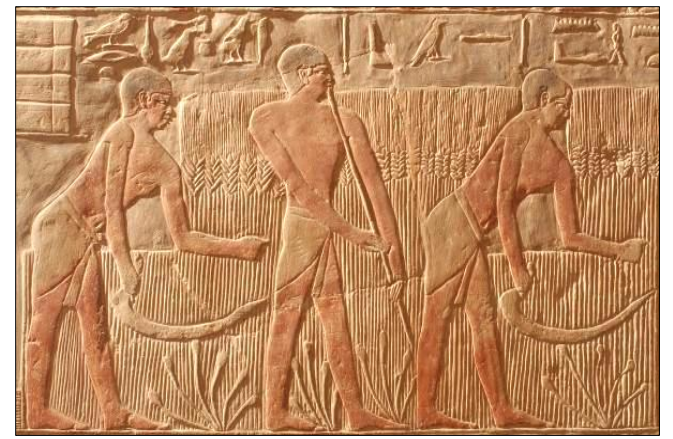

Figure (6) Flute player in the tomb of Mereruka

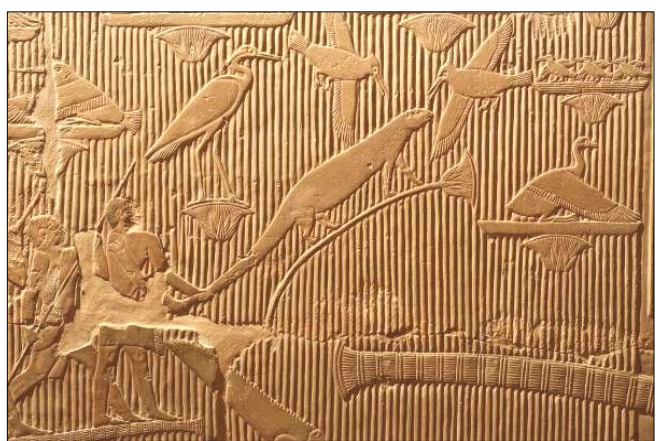

Figure (8) Catching an Egyptian mongoose in the tomb of Mereruka

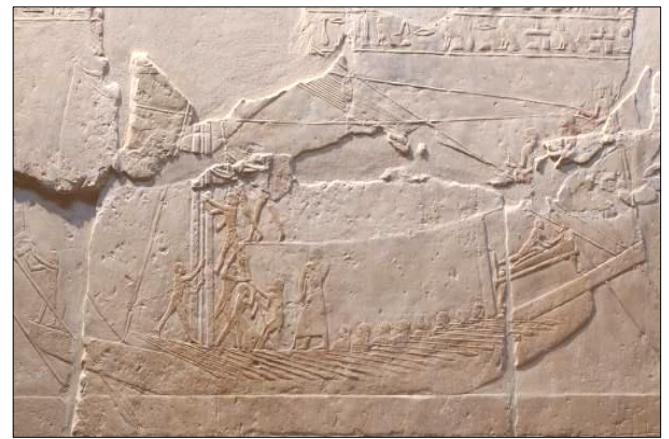

Figure (9) Mereruka standing amidships while a servant is preparing the bed 


\section{Conclusion}

The evidence suggests that Mehu had royal blood and was also married to a daughter of a king, possibly Wenis. He held the vizierate under Wenis, Teti and early under Pepy I, and accordingly during Weserkare's reign, when his stone mastaba was cased with thick brick walls, perhaps to hide the façade inscriptions referring to his kinship to Shepsipuptah and to King Teti. Two probable sons of Mehu, Meryreankh and Hotepka were later buried in his mastaba. The architecture of Mehu's mastaba seems to have been inspired by those of Ti and Ptahhotep I, and all three influenced other mastabas, such as that of Mereruka. The artists of Mehu's chapel were very competent and paid special attention to the individual features of the workmen. However, the sculptor of Meryreankh was less able, but a master painter corrected his work. The decoration of the portico walls, belonging to Hotepka, shows less merit. Striking similarities in subject matters and details between the scenes in Mehu's tomb and that of Mereruka are evident. Examples may be seen in the flute players entertaining the harvesters of the grain and in the attendants catching Egyptian mongooses by the tail in the fowling scenes. In the pilgrimage trip Mehu is depicted asleep on a bed at the stern of the boat, and Mereruka is depicted standing while a servant is preparing the bed. Comparison with other tombs is also informative. For example the mating crocodiles are found in the tombs of Mehu, Kagemni and Hesi. The crocodiles swallowing fish headfirst appear in the tombs of Khnumenti at Giza and Mehu, Kagemni and Mereri at Saqqara. The high-kicking dance is seen in the tombs of Mehu, Kagemni, Ankhmahor, and Merefnebef. However, the aggressive scenes found for instance in Mereruka's chapel are missing in that of Mehu, which may reflect his personality.

\section{References}

[1] Altenmüller, H., (1998). Die wanddarstellungen im grab des Mehu in Saqqara, Verlag Philipp von Zabern , Mainz am Rhein, Germany.

[2] Harpur, Y. \& Scremin, P., (2006). The chapel of Kagemni, Oxford expedition to Egypt (OEE), Oxford, UK, idem, (2008). The chapel of Ptahhotep, Oxford expedition to Egypt (OEE), Oxford, UK.

[3] Moussa, A. \& Altenmüller, H. (1971). The tomb of Nefer and Ka-hay, Verlag Philipp von Zabern, Mainz am Rhein, Germany

[4] Kanawati, N. \& Abder-Raziq, M., (2003). The Unis cemetery at Saqqara II, Aris \& Phillips, Oxford UK.

[5] Kanawati, N., (2010). The vizier nebet and the royal women of the sixth dynasty, in: Hawass, Z. \& Ikram, S. (ed.) Thebes and beyond: studies in honour of Weeks, K., Supreme council of antiquities, Egypt, pp: 120: 129.

[6] Baud, M. (1999). Famille royale et pouvoir sous l'Ancient Empire égyptien II, Journal de L'institut Français d'archéologie Orientale, pp: 580-582
[7] Firth, C. \& Gunn, B. (1926). Teti pyramid cemeteries II, Le Caire impri-merie de l'institut Français d'archéol-ogie orientale, Cairo; Kanawati, N. \& Hassan, A. (1996). The Teti cemetery at Saqqara, Vol. I, The Australian centre for Egyptology, Sydney, Australia

[8] Borchardt, L. (1937). Denkmäler des alten reiches, I: Catalogue général des antiquités égypyiennes du Musée du Caire, Organisme général des imprimeries gouvernementales, Berlin.

[9] De G. Davies, N. (1902). The Rock tombs of Deir el-gebrâwi I, Egypt exploration society, London. UK

[10] Kanawati, N. (2007). Deir elgebrawi II: The Southern cliff, the tomb of Ibi and others, Aris \& Phillips, Oxford, UK

[11] Jones, D. (2000). An index of ancient Egyptian titles, epithets and phrases of the old kingdom, BAR international series 886, Oxford, UK

[12] Martin-Pardey, E. (1976). Untersuchungen zur ägyptischen Provinzialverwaltung bis zum Ende des Alten Reiches, Verlag Gebrüder Gerstenberg, Hildesheim. Germany 
[13] Kanawati, N. \& Hassan, A. (1997). The Teti cemetery at Saqqara, Vol. II, Aris \& Phillips Ltd., Warminster, UK.

[14] Lloyd, B., El-Khouly, A. \& Spencer, J. (2008). Saqqâra tombs III: The mastaba of Neferseshemptah, Egypt exploration society, London. UK.

[15] Duell, P. (1938). The mastaba of Mereruka, 2 vols. Chicago university Press, USA; Kanawati, N. \& AbderRaziq, M. (2004). Mereruka and his Family I, Aris \& Phillips, Oxford, UK.

[16] James, T. (1953). The mastaba of Khentika called Ikhekhi, Egypt exploration society, London, UK.

[17] Épron, L. \& Daumas, F. (1939). Le tombeau de $\mathrm{Ti}$, fasc. I, L'institut Français d'archéologie Orientale, Egypt.

[18] Strudwick, N. (1985). The administeration of Egypt in the old kingdom, KPI limited, London, UK; Harpur, Y. (1987). Decoration in Egyptian tombs of the old kingdom, KPI limited, London. UK

[19] Hassan, S. (1975). Excavations at Saqqara II: Mastabas of Ny-aankhPepy and others, in: Iskander, Z. (ed.) General organization for government printing offices, Cairo, Egypt

[20] De G. Davies, N. (1900). The mastaba of Ptahhetep and Akhethetep at Saqqara, 2 Vols, Egypt exploration society, London, UK.
[21] Hassan, S. (1975). Excavations at Saqqara I: The mastaba of Neb-KawHer, in: Iskander, Z. (ed.) General organization for government printing offices, Cairo, Egypt

[22] Kanawati, N. (2006). The Teti cemetery at Saqqara, Vol. VIII, Aris \& Phillips Ltd., Oxford, UK.

[23] Evans, L. (2010). Animal behaviour in Egyptian art, Aris \& Phillips Ltd., Oxford, UK.

[24] Kanawati, N. \& Abder-Raziq, M. (1999). The Teti cemetery at Saqqara, Vol. V, Aris \& Phillips Ltd. Oxford, UK.

[25] Brovarski, E. (2001). The Senedjemib Complex, Vol. I, Museum of Fine Arts, Boston, USA

[26] Davies, W., El- Khouli, A. Lloyd, A. \& Spencer, A. (1984). The mastabas of Mereri and Wernu, Egypt exploration society, London, UK

[27] Mysliwiec, K. (2004). Saqqara I: The tomb of Merefnebef, Editions Neriton, Varsovie, Poland.

[28] Kanawati, N. (1999). Some iconographic peculiarities in the Teti cemetery, in: Ziegler, Ch. (ed.) L'art de l'Ancien empire égyptien, Paris, documentation française, pp: 281310.

[29] Kanawati, N. (2007). Mereruka and King Teti: The power behind the throne, Supreme council of antiquities, Cairo, Egypt 